\title{
Pearls \& Oy-sters: Facial nerve palsy in COVID-19 infection
}

Yihui Goh, MRCP(UK), * Darius L.L. Beh, MRCP(UK), * Andrew Makmur, FRCR, Jyoti Somani, MD,† and Amanda C.Y. Chan, MRCP(UK)†

Neurology ${ }^{\circledR}$ 2020;95:364-367. doi:10.1212/WNL.0000000000009863

\section{Pearls}

- Coronavirus disease 2019 (COVID-19) has been associated with various neurologic manifestations, including anosmia, acute ischemic stroke, Guillain-Barré syndrome, and encephalopathy.

- During the COVID-19 pandemic, physicians seeing patients with these neurologic manifestations should consider COVID-19 as a differential diagnosis to prevent diagnostic delays and further transmission of disease.

- Cranial nerve involvement could potentially be associated with COVID-19.

\section{Oy-sters}

- When a patient presents with isolated facial nerve palsy, a careful neurologic examination is required to rule out concomitant cranial nerve involvement (such as trigeminal nerve or vestibulocochlear nerve palsies) that would suggest alternative localization sites.

- Facial nerve palsy is commonly due to, or associated with, a viral infection and should not be assumed to be idiopathic.

- Investigations such as CSF analysis and MRI can be helpful in evaluating for CNS infection, inflammation, and other secondary causes.

In early March 2020, a previously healthy 27-year-old man was admitted directly to the isolation ward of a tertiary health care center in Singapore with symptoms of myalgia, cough, and fever for 4 days. His symptoms started the day after he returned from Spain. He also complained of a new left-sided throbbing headache with no associated photophobia or neck stiffness. On examination, he had mild bilateral conjunctival injection and respiratory examination was unremarkable. He did not have any focal neurologic deficits. Chest radiography did not show any infiltrates and a nasopharyngeal swab returned positive for severe acute respiratory syndrome coronavirus 2 (SARS-CoV-2) on real-time reverse transcription PCR (RT-PCR) assay.

On the third day of hospitalization (day 6 of illness), the patient developed left facial weakness, which was preceded by left retro-auricular pain and dysgeusia. Neurologic examination revealed involvement of the left frontalis, orbicularis oculi, buccinator, and orbicularis oris, consistent with a left lower motor neuron type facial nerve palsy. Corneal reflex was present, and there was no hyperacusis. The rest of the neurologic examination was unremarkable and his reflexes were normal. Kernig and Brudzinski signs were negative. There were no associated vesicles in the outer ear nor was there any parotid swelling. HIV screen was negative. CSF analysis did not show any pleocytosis, and glucose and protein levels were normal. CSF PCR for herpes simplex virus (HSV), varicella-zoster virus (VZV), Epstein-Barr virus, and cytomegalovirus and RTPCR for SARS-CoV-2 were negative. MRI of the brain showed enhancement of the left facial nerve (figure, A). He was started on prednisone and valacyclovir for treatment of Bell palsy.

\author{
Correspondence \\ Dr. Chan \\ Amanda_chan@nuhs.edu.sg
}

\section{MORE ONLINE}

COVID-19 Resources

For the latest articles, invited commentaries, and blogs from physicians around the world

NPub.org/COVID19

*These authors contributed equally to this work as co-first authors.

tThese authors contributed equally to this work as co-last authors.

From the Divisions of Neurology (Y.G., A.C.Y.C.) and Infectious Diseases (D.L.L.B., J.S.), Department of Medicine, National University Health System; and Department of Diagnostic Imaging (A.M.), National University Hospital, Singapore.

Go to Neurology.org/N for full disclosures. Funding information and disclosures deemed relevant by the authors, if any, are provided at the end of the article. 
Lopinavir/ritonavir was also initiated with the intention of reducing SARS-CoV-2 viral replication. His SARS-CoV-2 viral load was high during the early phase of illness (4-7 days from symptom onset) and decreased rapidly following the administration of lopinavir/ritonavir, becoming undetectable by the end of the second week (figure, B). No significant virologic rebound was observed. On review 1 week later, there was no significant change in the degree of his facial weakness, but his headache and retroauricular pain improved.

\section{Discussion}

We are in the exponential phase of learning about COVID-19, an emerging infectious disease, which has caused an ongoing global pandemic. In a cohort of 214 Chinese patients, COVID-19 presents most commonly with fever in $88.7 \%$ and cough in $67.8 \%$ of patients, $5 \%$ of whom required intensive care monitoring. ${ }^{1}$ Neurologic manifestations of COVID-19 have been reported in up to $36.4 \%$. $^{2}$ Thus far, impairment of taste and smell, dizziness, and headache have been reported as common symptoms in COVID-19. ${ }^{2}$

Recently, reports of significant neurologic associations have emerged, including increased incidences of Guillain-Barré syndrome, encephalopathy, and strokes. ${ }^{2-5}$ In an Italian cohort, Guillain-Barré syndrome has been reported in approximately $0.5 \%$ of patients with COVID-19, with the first symptoms of flaccid paralysis and facial diplegia occurring at 5-10 days after onset of acute respiratory symptoms. ${ }^{5}$ In Strasbourg, France, encephalopathic features were commonly seen in patients with severe COVID-19 who had acute respiratory distress syndrome, some of whom had MRI abnormalities including leptomeningeal enhancement, perfusion abnormalities, and ischemic stroke. ${ }^{4}$ A case of acute hemorrhagic necrotizing encephalopathy associated

Figure Neuroimaging and viral load of a patient with coronavirus 2019 with facial nerve palsy

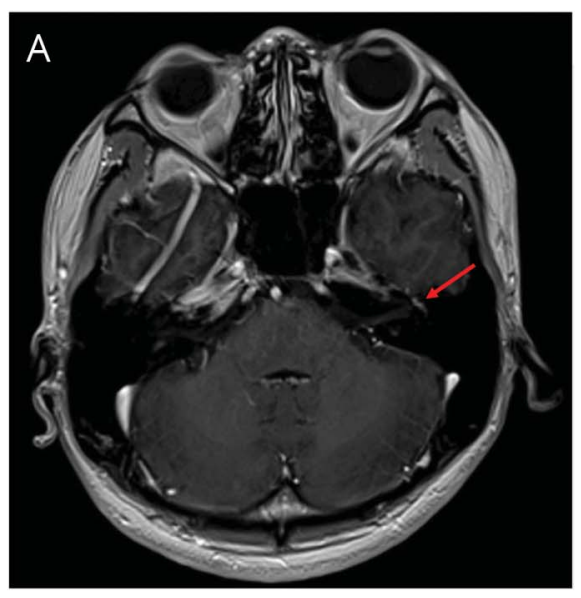

B
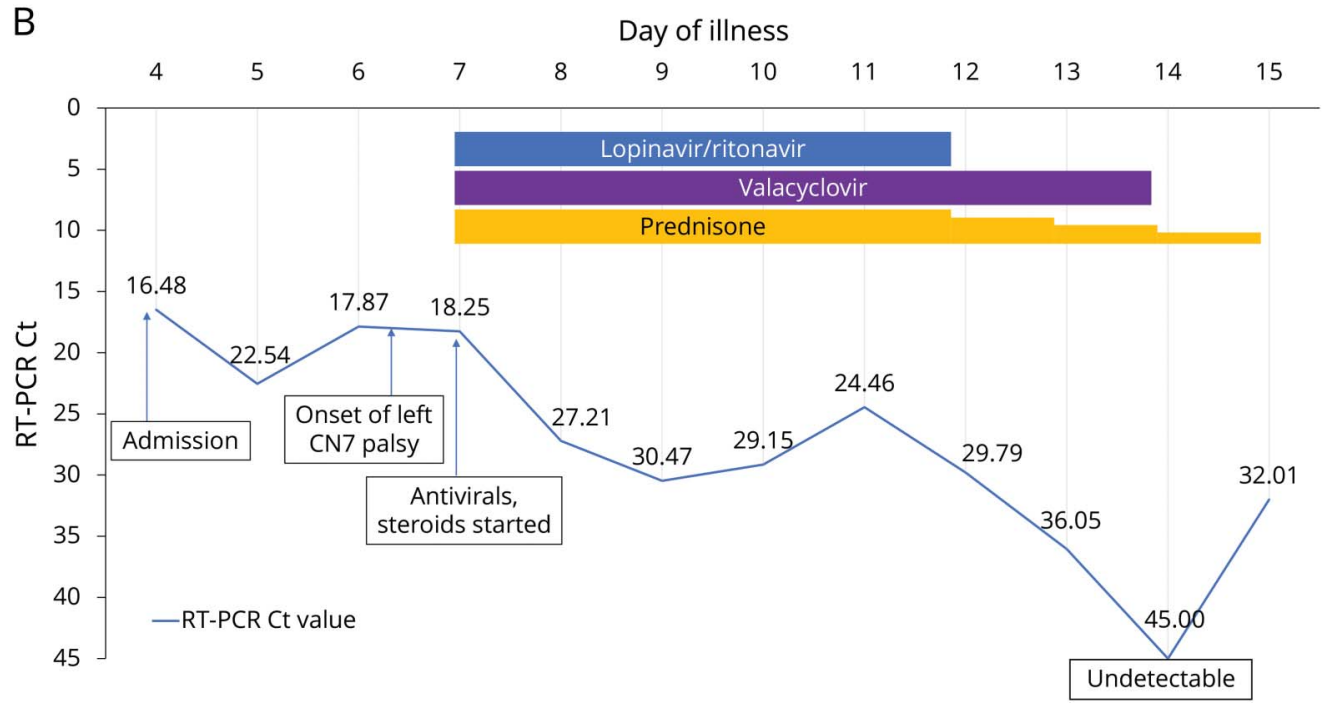

(A) Contrast-enhanced MRI of the brain showing enhancement of the left facial nerve (arrow). (B) Severe acute respiratory syndrome coronavirus 2 viral load correlated with clinical course and treatment. RT-PCR = real-time reverse transcription PCR. 
with COVID-19 infection has also been reported in Detroit, Michigan, and postulated to be due to intracranial cytokine storm, with MRI showing T2 fluid-attenuated inversion recovery hyperintensities within the thalami and bilateral medial temporal lobes with rim enhancement post contrast. ${ }^{3}$ The incidence of stroke was $5.7 \%$ in patients with COVID-19 with more severe respiratory symptoms in Wuhan, China. ${ }^{2}$ A case series from Spain described cranial nerve manifestations associated with COVID-19 in 2 patients, 1 of whom had Miller Fisher syndrome and the other presenting with polyneuritis cranialis. ${ }^{6}$ To our knowledge, isolated cranial neuropathies have yet to be described.

Facial nerve palsy can be associated with infections, most commonly HSV, as well as VZV and HIV, Lyme disease, and Mycobacterium tuberculosis. Noninfectious causes include sarcoidosis and neoplasms. The exact pathogenesis of acute facial nerve palsy remains unclear, but in association with neurotropic herpesviruses (HSV and VZV), it is thought to be related to axonal spread and viral replication leading to inflammation and demyelination. ${ }^{7}$

Coronaviruses are known to have a neuroinvasive propensity. Animal models show that severe acute respiratory syndrome coronavirus and Middle East respiratory syndrome coronavirus could potentially have a transcribial route to the brain, causing CNS manifestations. ${ }^{8}$ The mechanism underlying neurologic symptoms in COVID-19 has yet to be clearly elucidated. Similar to the patients with Miller Fisher syndrome and perineuritis cranialis described in Spain and those with Guillain-Barré syndrome described in Italy, our patient developed an isolated facial nerve palsy during the early phase of his illness, on day $6 .^{5,6}$ This may suggest a parainfectious phenomenon. Serum GD1b immunoglobulin $\mathrm{G}$ antibodies were also detected in the patient with Miller Fisher syndrome. In all of these cases with Guillain-Barré syndrome and Miller Fisher syndrome, SARS-CoV-2 was not detected in the CSF. As such, cranial neuropathies may be related to immune-mediated injury from proinflammatory cytokines rather than direct viral neutrophism. ${ }^{6}$

Studies of viral dynamics show that viral loads are highest 1-2 days prior to symptom onset, and decrease in a monotonic pattern with prolonged viral shedding hovering near the level of detection, resulting in RT-PCR results that vacillate between positive and negative. 9 Lopinavir/ ritonavir is a protease inhibitor combination approved for use in HIV-1 and has demonstrated in vitro activity against SARS-CoV-2. A recent randomized trial conducted in China on patients with COVID-19 with severe respiratory symptoms compared lopinavir/ritonavir, in addition to standard care, to standard care alone, and found no significant decrease in viral load or clinical benefit with lopinavir/ ritonavir. ${ }^{10}$ However, in this study, the frequency of RT-PCR testing was only every 4-7 days, and it has been proposed that daily sampling following antiviral treatment may have provided more detailed characterization of the viral load kinetics. More studies are needed to determine if there is a direct effect of lopinavir/ritonavir on viral load, an indirect effect on the immune response, or no effect on the natural course of the disease process. In our patient, we observed a declining trend in SARS-CoV-2 viral load (which is inversely related to the cycle threshold or $\mathrm{Ct}$ value) determined by daily nasopharyngeal swab samples after lopinavir/ritonavir was initiated.

This case report only suggests a possible association between isolated cranial neuropathies and COVID-19. More cases are required to support causality. We are reporting this case to inform and alert physicians of the possibility of cranial nerve involvement in the presentation of patients with COVID-19.

\section{Study funding}

No targeted funding reported.

\section{Disclosure}

The authors report no disclosures relevant to the manuscript. Go to Neurology.org/N for full disclosures.

\begin{tabular}{|c|c|c|}
\hline Name & Location & Contribution \\
\hline $\begin{array}{l}\text { Yihui Goh, } \\
\text { MRCP(UK) }\end{array}$ & $\begin{array}{l}\text { Division of Neurology, } \\
\text { Department of Medicine, } \\
\text { National University Health } \\
\text { System, Singapore }\end{array}$ & $\begin{array}{l}\text { Conception, } \\
\text { organization, and } \\
\text { execution of the } \\
\text { research project; writing } \\
\text { of the first draft; review } \\
\text { and critique of the } \\
\text { manuscript }\end{array}$ \\
\hline $\begin{array}{l}\text { Darius L.L. } \\
\text { Beh, } \\
\text { MRCP(UK) }\end{array}$ & $\begin{array}{l}\text { Division of Infectious } \\
\text { Diseases, Department of } \\
\text { Medicine, National } \\
\text { University Health System, } \\
\text { Singapore }\end{array}$ & $\begin{array}{l}\text { Conception, organization, } \\
\text { and execution of the } \\
\text { research project; writing } \\
\text { of the first draft; review } \\
\text { and critique of the } \\
\text { manuscript }\end{array}$ \\
\hline $\begin{array}{l}\text { Andrew } \\
\text { Makmur, } \\
\text { FRCR }\end{array}$ & $\begin{array}{l}\text { Department of Diagnostic } \\
\text { Imaging, National University } \\
\text { Hospital, Singapore }\end{array}$ & $\begin{array}{l}\text { Execution of the } \\
\text { research project; review } \\
\text { and critique of the } \\
\text { manuscript }\end{array}$ \\
\hline $\begin{array}{l}\text { Jyoti } \\
\text { Somani, } \\
\text { MD }\end{array}$ & $\begin{array}{l}\text { Division of Infectious } \\
\text { Diseases, Department of } \\
\text { Medicine, National } \\
\text { University Health System, } \\
\text { Singapore }\end{array}$ & $\begin{array}{l}\text { Conception, organization, } \\
\text { and execution of the } \\
\text { research project; review } \\
\text { and critique of the } \\
\text { manuscript }\end{array}$ \\
\hline $\begin{array}{l}\text { Amanda } \\
\text { C.Y. Chan, } \\
\text { MRCP(UK) }\end{array}$ & $\begin{array}{l}\text { Division of Neurology, } \\
\text { Department of Medicine, } \\
\text { National University Health } \\
\text { System, Singapore }\end{array}$ & $\begin{array}{l}\text { Conception, organization, } \\
\text { and execution of the } \\
\text { research project; writing } \\
\text { of the first draft; review } \\
\text { and critique of the } \\
\text { manuscript }\end{array}$ \\
\hline
\end{tabular}

\section{References}

1. Guan WJ, Ni ZY, Hu Y, et al. Clinical characteristics of coronavirus disease 2019 in China. N Engl J Med 2020;382:1708-1720.

2. Mao L, Jin H, Wang M, et al. Neurologic manifestations of hospitalized patients with Coronavirus disease 2019 in Wuhan, China. JAMA Neurol 2020;77:683-690. 
3. Poyiadji N, Shahin G, Noujaim D, Stone M, Patel S, Griffith B. COVID-19-associated acute hemorrhagic necrotizing encephalopathy: CT and MRI features. Radiology Epub 2020 Mar 31.

4. Helms J, Kremer S, Merdji H, et al. Neurologic features in severe SARS-CoV-2 infection. N Engl J Med 2020;382:2268-2270.

5. Toscano G, Palmerini F, Ravaglia S, et al. Guillain-Barré syndrome associated with SARS-CoV-2. N Engl J Med Epub 2020 Apr 17.

6. Gutiérrez-Ortiz C, Méndez A, Rodrigo-Rey S, et al. Miller Fisher syndrome and polyneuritis cranialis in COVID-19. Neurology Epub 2020 Apr 17.
7. Eviston TJ, Croxson GR, Kennedy PGE, et al. Bell's palsy: aetiology, clinical features and multidisciplinary care. J Neurol Neurosurg Psychiatry 2015;86:1356-1361.

8. Li YC, Bai WZ, Hashikawa T. The neuroinvasive potential of SARS-CoV2 may play a role in the respiratory failure of COVID-19 patients. J Med Virol 2020;92: $552-555$.

9. He X, Lau EHY, Wu P, et al. Temporal dynamics in viral shedding and transmissibility of COVID-19. Nat Med 2020;26:672-675.

10. Cao B, Wang Y, Wen D, et al. A trial of lopinavir-ritonavir in adults hospitalized with severe COVID-19. N Engl J Med 2020;382:1787-1799.

\section{NEW EPISODE}

\section{ค}

$\underset{\text { PODCAST }}{\text { Neurology }}$

August 25, 2020

\section{Diagnosis of prion diseases by $\mathrm{RT}-\mathrm{QuIC}$ results in improved surveillance (see p. 338)}

Dr. Gregg Day and Dr. Brian Appleby talk about Dr. Appleby's paper discussing diagnostic testing for prion disease. In the 2nd of a 4-part series on managing ischemic stroke, Dr. Andrew Southerland talks with Dr. Dan Ackerman.

Disclosures can be found at Neurology.org.

CME Opportunity: Listen to this week's Neurology Podcast and earn 0.5 AMA PRA Category 1 CME Credits ${ }^{\mathrm{TM}}$ by completing the online Podcast quiz.

\section{Visit the Neurology ${ }^{\circledR}$ Resident \& Fellow Website}

Click on Residents \& Fellows tab at Neurology.org.

Now offering:

- Neurology ${ }^{\circledR}$ Resident \& Fellow Editorial team information

- "Search by subcategory" option

- E-pearl of the Week

- RSS Feeds

- Direct links to Continuum ${ }^{\circledR}$, Career Planning, and AAN Resident \& Fellow pages

- Recently published Resident \& Fellow articles

- Podcast descriptions

- Blogs by Editors and Resident \& Fellow team members

f Find Neurology ${ }^{\circledR}$ Residents \& Fellows Section on Facebook: facebook.com/AANResidentsAndFellows

Follow Neurology ${ }^{\circledR}$ on Twitter: @GreenJournal \#NeurologyRF

(ㄱ) Find Neurology ${ }^{\circledR}$ Residents \& Fellows Section on Instagram: @aanbrain \#NeurologyRF 


\section{Neurology}

\section{Pearls \& Oy-sters: Facial nerve palsy in COVID-19 infection \\ Yihui Goh, Darius L.L. Beh, Andrew Makmur, et al. \\ Neurology 2020;95;364-367 Published Online before print May 21, 2020 \\ DOI 10.1212/WNL.0000000000009863}

This information is current as of May 21, 2020

Updated Information \&
Services

References

Subspecialty Collections

Permissions \& Licensing

Reprints including high resolution figures, can be found at:

http://n.neurology.org/content/95/8/364.full

This article cites 7 articles, 1 of which you can access for free at: http://n.neurology.org/content/95/8/364.full\#ref-list-1

This article, along with others on similar topics, appears in the following collection(s):

Cranial neuropathy

http://n.neurology.org/cgi/collection/cranial_neuropathy

MRI

http://n.neurology.org/cgi/collection/mri

Information about reproducing this article in parts (figures,tables) or in its entirety can be found online at:

http://www.neurology.org/about/about_the_journal\#permissions

Information about ordering reprints can be found online:

http://n.neurology.org/subscribers/advertise

Neurology ${ }^{\circledR}$ is the official journal of the American Academy of Neurology. Published continuously since 1951, it is now a weekly with 48 issues per year. Copyright @ 2020 American Academy of Neurology. All rights reserved. Print ISSN: 0028-3878. Online ISSN: 1526-632X.

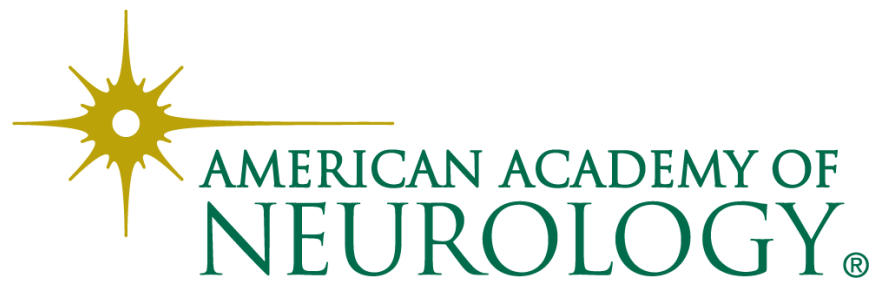

